Stansted would have been a greater nuisance on the the grounds of noise than an airport at one of the several alternative sites on the Thames Estuary.

There are, however, more serious charges to be made against the way in which the site at Stansted was selected. Looking back, it is clear that the case for Stansted was unreasonably influenced by the preexistence of a single concrete runway at the site-a circumstance which could not have saved more than ten per cent of building on the site even on the basis of the Govornment's calculations. Also included in these calculations was the comic guess that it would cost no more than $\mathfrak{E} 6$ million of capital to improve existing transport links with the proposed airport to the point at which they could be considered good enough for the year 2000 (when the third London airport will presumably be still in service). But to argue like this is absurd. In setting out to compare the costs of alternative sites, the Government should seek to do for airports what it insists the nationalized industries should do when making decisions about the new investments on capital equipment-some attempt should be made to lump together running costs and capital costs. And the truth is, of course, that in circumstances in which the annual flow of passengers through the new airport is likely to be several tens of millions in the eighties, cheescparing now about the initial cost is likely to be an exceedingly false economy. The real need is for a much more realistic appraisal of the full costs of alternative sites from the point of view of the whole function of the airport and the whole complex of potential users. It is particularly important to graft on to the study which is now to be undertaken - and Mr Crosland has promised that it will be a thoroughly comprehensive inquiry even though there are misgivings about the time that that will take-a proper study of the surface transport, freight as well as passengers. The object should be to regard the new and non-existent airport as a part of a huge and integrated system and not as an isolated facility by itself. It is, in other words, a splendid opportunity. It will be interesting to see how well the Government rises to the occasion after making such a mess of its first attempt to choose a site.

\title{
What Takers for Dr Dainton's Cure?
}

Three years almost to the day after the appointment of the committee under Dr F. S. Dainton which has been looking into the causes for the drift away from science in British schools, the final report has been published. On the whole, it is a perceptive and a liberal document. Although the committec was charged with responsibility simply for the problem of the diminishing flow of young people into scicnec and technology at the interface between British schools and the various establishments of higher education, it has creditably taken a wider view of its task. In particular, it has quite accurately concluded that much of what it wishes to accomplish can only be done by reconstruction of the British educational system. (To be accurate, the Dainton Committee has also acknowledged what seems to be the superiority of the Scottish system in comparison with what happens south of the border, and urges that the Scots should set their faces against supposed reforms of their system the effect of which would be to make the interaction between schools and universities in Scotland resemble more closely the relationship which now obtains in the rest of Britain.) Fortunately, the need for ehange is now more widely appreciated than it has ever been, and it is not unreasonable to hope that a measure of change may actually come about. In the circumstances, the Dainton Report is likely to find a more sympathetic reception than would have seemed likely even a year ago. By the same test, unfortunately, its historical importance is likely to be less than if it had appoared sooner, when the going was still rough.

The swing away from sciense in British schools is, of course, a comparative affair. The groups of young people following science studies in the sixth forms of British schools are still a growing proportion of the age group as a whole, but the groups following other kinds of studies are growing muoh more rapidly. The result is that the balance between science studies and other studies in the senior classes of British schools is changing rapidly and to the detriment of the sciences. One consequence is the difficulty there has been in recent years in recruiting people to fill the science departments at universities to their bost advantage. The Dainton Committee is right to take the view that this trend cannot be a healthy one at a time when there is a large unsatisfied demand for technical people in commerce and industry, and when science and technology as a whole are capable not merely of changing the character of life but of exciting the imagination as well. Sensibly enough, however, the committee has set its face not merely against expedients that would artificially persuade young people to suppress their natural inclinations but also against attempts to develop artificial rules for saying how many people with which kinds of training British higher education should provide.

So what, then, should be done ? Schools and uníversities have separate parts to play, but it is entirely proper that the Dainton Committee should put high on its list of remedies the vicw that British schools should provide a much broader curriculum for their pupils. This, of course, is a erying need which even Scotland should not ignore. The question which now needs to be answered is what kind of reform should now be undertaken. It has been an open secret for several months that the Dainton Committee would urge that only in the most exceptional circumstances should pupils in British schools be allowed to abandon mathematics, which is entirely sensible. But what form should the rest of the curriculum take? The Dainton Committee has obviously been attracted by 
the talk in recent months of schemes in which students preparing for higher education would study three or four subjects as well as mathematics, and its own preference is for a mixture of science, social science and arts for everybody. So far, so good. The real problem is to know what should be done to bring about these changes.

The committee would have done a useful service if it had been more outspoken on this issue. Events in the last six months suggest that the time has come when several distinguished heads should be knocked forcibly together, and the Dainton Committee could have made a useful start. For one thing, it is important that the Schools Council, which has responsibility for the British school curriculum, should be dissuaded from its introspective preoccupation, the pressure of external examinations (and the need somehow to diminish it). Its own proposals are narrowing, not broadening, and have served so far chiefly to undermine confidence in the council's capacity to function sensibly. But it is also important that work should promptly be put in hand to design the kinds of curricula which the logic of the committee's proposals would imply, and on recent form there is very little to suggest that the Schools Council, which ought to be in charge, will be fit and able to do what is expected of it. But there are also problems concerning teachers' organizationswho, for example, is going to persuade the science teachers whose enthusiasm has been chiefly responsible for experiments in science teaching in recent years that the time has now come to have less, not more, formal teaching in the schools? One of the valuable discoveries which the Dainton Committee has to report is that students following science courses tend to be well looked after by well qualified teachers. The question now is who should tell these talented people that they must spend less time behaving as if they were teaching in universities. To be sure, it will be valuable to have Dr Dainton's support for the cause of more in-service training for teachers, more laboratory technicians in British schools and better means of persuading young people to take up science teaching. The trouble, unfortunately, is that these needs have also been obvious for some time. The most urgent need has become that of making them materialize.

\section{The Magic of Numbers}

THE dead-pan send-up is a literary genre that seems now to be flourishing in the United States. A few weeks ago there was the Report from the Iron Mountain. Now there has appeared Professor D. J. de S. Price's Research on Research (Journeys in Science, University of New Mexico Press, 1967). It is true that Professor Price appears to be entirely serious in what he has to say, but many of his readers will be bound to suspect that he has devised a witty demonstration of the inadequacies of what is called the science of science.

That hindsight makes it seem as if scientific discovery points to a logical method of procedure has led some people to suppose that there must be an
It is, of course, a great absurdity that the British educational system has remained archaic for so lung, but the prize will go to the one who can show how change can happen quickly.

What the committee has to say about the universities follows naturally enough-universities must be more flexible about their requirements for entry. By good fortune, it seems now very much as if the Standing Conference on University Entrance will be given advice in this direction in the months ahead. The article by Professor L. Rosenhead, a member of the Dainton Committee, on page 806, is one man's vision of how universities might quickly become better suited to the real needs of the schools. But here, too, it is all too likely that the formal processes of consultation and the traditional unwillingness of those concerned with British education to consider seriously any but the most moderate of changes will blunt the present tendency towards reform.

This, perhaps, is where the Government could help. As it has turned out, and as it should be, the Dainton Report is not a piece of special pleading on behalf of science teachers but yet another comment on the inadequacies of British education. It also stands out among public documents as a sensible statement of the part which should be played in education by science studies and of the reasons why some acquaintance with science should be considered important not merely for professional scientists but for everybody. The trouble, of course, is that in the present balance between British schools and British universities, there is no room for this kind of appraisal. On the whole, the schools are too preoccupied with specialist studies and the universities are forced as a result to be too preoccupied with the need for a broader education. It is hard to see how this pattern can be changed except by the simultaneous agreement of the host of interested parties, but it is also plain that the need for change is urgent. In the circumstances the Government could do worse than organize the kind of conference at which many interested parties could be persuaded to hammer out answers to the question which excessive modesty has persuaded. Dr Dainton to leave alone.

analogous logic in the way in which science is carried on -a logic the investigation of which merits a new and distinct discipline of social enquiry. One approach of this "discipline" is to examine some numerical parameter assumed to be indicative of the forward march of science, such as the number of all papers published, and if possible to describe its variation in terms of some mathematical function. From this kind of exercise, scientists of science expect, some useful insight may eventually emerge. Among the principal difficulties of this argument is the assumption that the part of the individual in scientific discovery is either so predictable or so negligible that it can be altogether 